\title{
ELIMINATING OBSTACLES TO FREEDOM OF ESTABLISHMENT: THE COMPETITIVE EDGE OF UK COMPANY LAW
}

\author{
JOHN LOWRY*
}

Two recent decisions of the European Court of Justice have now addressed major questions left largely unresolved by its earlier jurisprudence. First, whether or not the determination of lex societatis can continue to be tested by reference to the real seat doctrine notwithstanding the Court's (hereafter referred to as the ECJ) landmark decision in Centros Ltd. v. Erhversus-og Selkabssyrelsen. ${ }^{1}$ This has now been thrown into doubt following the decision in Überseering $B V$ v. Nordic Construction Company Baumanagement $G m b H^{2}$ The case is significant in that it appears to spell the end of the seat principle as a viable national rule of conflicts law. The second and broadly related question concerns the extent to which a Member State may by national laws present obstacles to companies coming in to it from other Member States. The issue here is whether the right to freedom of establishment precludes national legislation in a Member State from imposing on the exercise of freedom of secondary establishment in that State by a company incorporated in another Member State certain conditions relating to minimum capital and directors' liability. This question arose in Kamer van Koophandel en Fabrieken voor

\footnotetext{
* University College London. I owe a debt of gratitude to Professor Marise Cremona, Loukas Mistelis, Rod Edmunds and the anonymous referees for their helpful comments on this paper. All remaining errors are my sole responsibility. I also thank Mads Andenas for making available to me material on Überseering. An earlier version of this paper was presented at a conference of the German Lawyer's Association (DAV) and the University of Cologne, Verdrängt Das Europäische Recht Das Nationale Gesellschaftsrecht, 30 October 2003.

${ }^{1}$ Case C212/97, [1999] E.C.R. I-1459. The ECJ held that Denmark was in breach of EU law in refusing to allow Centros Ltd., a private company registered in England, to establish a branch in Denmark even though it was in fact its primary operational establishment. The Court rejected the argument of the Danish authorities that the Danish owners of Centros Ltd. had chosen the UK as the state of incorporation of its undercapitalised company in order to avoid the minimum capital requirements required under Danish law. The motive of the owners could not be regarded as abusive but were a consequence of their freedom to incorporate a company in one Member State and set up a secondary establishment in another (para. 26-7). For comment, see E. Micheler, "The Impact of the Centros Case on Europe's Company Laws" [2000] Comp. Law. 179; and H. Xanthaki, "Centros: Is This Really The End For The Theory Of The Siège Réel" [2001] Comp. Law. 2.

2 Case C-208/00, November 5, 2002. See, Mads Andenas, "Free Movement of Companies" (2003) 119 L.Q.R. 221. See further, P. Dyrberg, "Full Free Movement of Companies in the European Community At Last" [2003] E.L.R. 528.
} 
Amsterdam v. Inspire Art Ltd., ${ }^{3}$ in which the ECJ roundly ruled against national laws that impede freedom of establishment.

The landscape against which these questions came before the ECJ must be viewed against two competing conflict of law theories that have come to fore in relation to companies seeking to transnationalise their sphere of operations. The issue arises because, as the cases reveal, a company may relocate its head office or centre of administration to a different Member State from that where it maintains its registered office. While it is perhaps surprising, especially in the wake of Centros, that Member States should continue to test the ECJ's position on transnational companies, the depth of the problem stems from the lack of synergy between key provisions of the EC Treaty which seek to further the internal market ideal (i.e. those relating to freedom of movement within the E.U. to carry out business in any Member State $^{4}$ ) on the one hand, and the conflicting private international law approaches towards the recognition of foreign companies on the other.

Within the EC Member States there are two dominant and seemingly entrenched theories of interlegal company law. The majority of continental countries subscribe to the "real seat" (siege réel) theory, ${ }^{5}$ whereby the courts view a company as being subject to the law of the jurisdiction where its seat or principal management is located. Put simply, the theory proceeds on the basis of residence in the way the residence of a company is determined under UK law for the purposes of tax. ${ }^{6}$ Thus, a company that is incorporated in England and maintains its registered office in London, for example, but moves its head office or centre of administration to Bonn, will be governed by German law (lex societatis). The "real seat" theory is primarily justified by its supporters by reference to the need for creditor and minority shareholder protection in that it deters the socalled "Delaware effect" whereby companies choose to register in a jurisdiction with a light touch regime while carrying on its business operations in another jurisdiction with a stricter regime. ${ }^{7}$ This has resulted in a tension between the rationale underlying the seat doctrine and the move towards the internal market. The ECJ has

\footnotetext{
${ }^{3}$ Case C-167/01, 30 September 2003.

${ }^{4}$ Notably EC Treaty, arts 2, 43 and 48.

5 Principally Germany, Austria, France, Belgium, Luxembourg, Greece, Italy, Spain and Portugal: see J. Wouters, "Private International Law and Companies' Freedom of Establishment" [2001] E.B.O.L.R. 101.

${ }^{6}$ De Beers Consolidated Mines v. Howe [1906] A.C. 455 (HL). See further, J.G. Collier Conflict of Laws (Cambridge 2001), pp. 58-59.

7 The argument here is that the seat doctrine prevents a "race to the bottom" among Member States who might otherwise compete to frame a company law regime which foreign companies find attractive.
} 
therefore been called upon to weigh the EC Treaty provisions governing freedom of movement of companies, ${ }^{8}$ with the objections raised by continental Member States against UK company law not requiring private companies to have a minimum capital fund. ${ }^{9}$ Against siège réel stands the incorporation theory whereby domicile is the decisive test. Under this theory a company is domiciled at the place of its incorporation and so the place of registration is the decisive factor in determining the recognition of a company. This is followed in the UK, Ireland, the Scandinavian countries and the Netherlands. Thus, in the example above, UK courts will regard the company as British and subject to UK company law because its registered office is in London irrespective of where its head office is located. ${ }^{10}$

The practical impact of these competing theories has significant implications for companies. In Germany, for example, where the seat test has mandatory application a Scheinauslandsgesellschaft, or pseudo-foreign company, is treated according to German company law principles. A company operating in Germany but which is registered elsewhere, is denied its legal persona and is generally viewed as a commercial partnership-offene Handelsgesellschaftproviding it is not a one-person enterprise. ${ }^{11}$ The foreign company is therefore stripped of its legal personality. One consequence of this is that should proceedings be brought in a German court in the name of such a company, the court may strike out the claim as inadmissible on the ground that it is a non-existent entity. ${ }^{12}$ German conflicts law thus applies substantive German law to foreign companies. Therefore, a company which decides to move its Head Office to Germany is well advised to reincorporate there if it is to maintain its juristic character. As far as the UK is concerned, apart from Part XXIII of the Companies Act 1985 which introduced a specific disclosure regime for branches of oversea companies, ${ }^{13}$ its company law accepts that such companies are

\footnotetext{
${ }^{8}$ EC Treaty, art 43 (art 52, pre-Amsterdam) and art 48 (art 58, pre-Amsterdam).

${ }^{9}$ In practice, UK private companies generally have a purely nominal share capital fund; approximately $80 \%$ of all such companies have a share capital of up to $£ 100$ : see DTI, Companies in 2001-2002, Table A7. As a result of the Second EC Company Law Directive public companies, on the other hand, are required to have a minimum share capital of not less than $£ 50,000$ : see the Companies Act 1985, s 118(1).

10 The policy is based on the freedom of the incorporators to determine the applicable law without regard being had to where the enterprise operates: see Wulf-Henning Roth, "From Centros to Üeberseering: Free Movement of Companies, Private International Law, and Community Law" [2003] I.C.L.Q. 178, pp. 183.

${ }^{11}$ See Roth, note 10 above. See also, Wouters, note 5 above.

12 See J.V. Staudinger, Kommentar zum Bürgerlichen Gesetzbuch mit Einführungsgesetz und Nebengesetzen -Internationales Gesellschaftsrecht, Neubearbeitung 1998 (Berlin 1998) paras. 427-430.

${ }^{13}$ Implementing the Eleventh Company Law Directive, Directive 89/666/EEC, [1989] O.J. L395/ 36. See B. Hannigan, Annotated Guide to the Companies Act (London 2001).
} 
primarily governed by the laws of their particular state of incorporation. The UK's pragmatic approach thus stands in marked contrast to the stance adopted in other Member States where the seat theory drives the courts to superimpose domestic law on foreign registered companies. Following Centros it seems that some continental Member States continued to cling to the hope that the seat doctrine which, it should be noted, was not explicitly referred to by the ECJ in its judgment, might have survived the Court's ruling. The question therefore arises whether, in the light of Überseering, ${ }^{14}$ and Inspire Art Ltd., ${ }^{15}$ the forces now ranged against the seat theory are unassailable. As a further twist, the cases afford clear illustrations of both the perceived problem that can arise from freedom of establishment of companies (i.e. the rush to the bottom (the "Delaware effect")) and national law mechanisms designed to counter that problem.

This article is in three parts. The first and second parts consider the arguments put forward by the respective parties in Überseering and Inspire Art in which the conflict between the competing theories relating to lex societatis came to the fore. The reasoning of the ECJ is examined with particular emphasis given to the tension between EC Treaty, arts 43 and 48 and the protective objectives of the national company laws that the particular Member States sought to enforce. This, in fact, led to the curious spectacle of the Dutch government in Inspire Art defending its anti-abuse statutory provisions from the stand point of the real seat theory while acknowledging that it subscribed to the incorporation theory. The final part concludes by examining the implications of the Court's stance and focuses upon the need for striking a balance between the notion that the overriding objective of modern company law should be directed towards facilitating enterprise, ${ }^{16}$ and the need to protect corporate constituencies, for example creditors situated in a Member State other than that

14 Above, note 2. Noted by D.E. Robertson, "Überseering: Nailing The Coffin On Sitztheorie" [2003] Comp Law 184. See further, F. Wooldridge, "Überseering: Freedom of Establishment of Companies Affirmed"'[2003] E.B.L.R. 227.

15 Above, note 3.

16 See Chapter II, General Themes, Final Report of the High Level Group of Company Law Experts on a Modern Regulatory Framework of Company Law in Europe (Brussels 2002), below note 34 . See also the approach taken by the UK government in its White Paper, Modernising Company Law (Cm. 5553-I and II). In establishing the High Level Group the European Commission sought its assistance in preparing a new proposal for a Directive on the conduct of takeovers and to define new priorities for the broader development of company law in the European Union. Three issues were initially referred to the Group for consideration: (i) how to ensure the existence of a level playing field in the E.U. concerning the equal treatment of shareholders across Member States; (ii) the definition of the notion of an "equitable price" to be paid to minority shareholders; and (iii) the right for a majority shareholder to buy out minority shareholders. It was during the second stage of the Group's deliberations that, inter alia, it was required to provide recommendations on how best to facilitate corporate restructuring and mobility. 
where the debtor company is incorporated, against abuses of limited liability.

\section{I. $\ddot{U}_{B E R S E E R I N G}$}

The facts are straightforward. The company, Überseering, was incorporated in the Netherlands in 1990. It purchased land in Germany and contracted with the Nordic Construction Company (NCC) to carry out building works on a garage and motel located on the site. When the work was completed Überseering complained that it was defective. In the meantime all of the shares in the company were transferred to two German nationals who lived in Düsseldorf. In 1996 Überseering begun proceedings against NCC in the Regional Court in Düsseldorf claiming damages for breach of contract. The defendant company successfully pleaded that the claim should be struck out on the basis that German private international law followed the real seat doctrine. It was argued that the real seat of the company, following the transfer of shares, was Düsseldorf, and because it was a company incorporated in the Netherlands, German law did not recognise its legal capacity. Consequently, Überseering lacked locus standi to bring the action. The Regional Appeal Court upheld the decision to strike the action out. On appeal, the Federal Supreme Court referred the issue, in the form of two questions, to the ECJ under EC Treaty, art 234 for preliminary ruling. First, are EC Treaty, arts 43 and 48 (the principle of freedom of establishment) to be construed so as to prevent a Member State determining legal personality and standing according to a company's real seat? Second, did freedom of establishment require Member States to apply the incorporation doctrine to determine a company's legal personality and standing?

The ECJ held that the particular application of German law doctrine was incompatible with Überseering's freedom of establishment as conferred by the EC Treaty. More particularly, the German requirement that a company must re-incorporate if it is to retain its legal personality in order to initiate legal proceedings for breach of contract was a clear infringement of EC Treaty, arts 43 and 48. A number of arguments were marshalled against the application of Centros. First, the submission of the governments of Germany, Spain and Italy and NCC that EC Treaty, art 293, which provides that Member States will enter in negotiations with a view to ensuring that conventions are in place for ensuring mutual recognition of companies and the continuation of a company's legal personality upon its transfer of seat to another Member State, reserved the legislative competence of Member States. This was 
roundly dismissed by the Court. Of particular interest and significance in this regard is the ECJ's interpretation of the decision in The Queen v. Treasury and Commissioners of Inland Revenue ex $p$ Daily Mail and General Trust, ${ }^{17}$ which was enlisted to support the argument that the issue of secondary establishment where a company relocates its seat is to be addressed by national legislation or conventions. Unlike Centros and Überseering, the facts of the Daily Mail case concerned the transfer of the Daily Mail's central management (real seat) to the Netherlands as a tax avoidance measure. The Daily Mail's application to the UK's Treasury for its consent to the move had been refused and so the company appealed to the High Court which referred the matter as a preliminary question to the ECJ in the following terms: whether EC Treaty arts 43 and 48 precluded a Member State from requiring that its prior consent is granted to a company wishing to transfer its Head Office to another Member State given that the transfer constituted a transfer of residence in order to avoid tax liability. The Court held that the EC Treaty confers no right on a company incorporated in one Member State to transfer its central management and control to another Member State. Not surprisingly then the German, Italian and Spanish governments relied on paragraph 23 of the judgment in Daily Mail:

The Treaty regards the differences in national legislation concerning the required connecting factor and the question whether-and if so how-the registered office or real head office of a company incorporated under national law may be transferred from one Member State to another as problems which are not resolved by the rules concerning the right of establishment but must be dealt with by future legislation or conventions.

The Court in Überseering sought to limit this statement by pointing out that the case concerned a company incorporated under UK company law wishing to transfer its central administration to another Member State without losing its legal personality or its status as a limited liability company under UK law, i.e. the State of incorporation. Thus, Daily Mail had no application to the problem of how one Member State should treat a company incorporated in another Member State which is seeking to exercise its freedom of establishment. Accordingly, the ECJ stated that the exercise of the freedom of establishment could not depend upon the adoption of conventions under art 293. It stressed that a necessary condition for the exercise of freedom of establishment was the recognition by Member States of those companies choosing to establish their

${ }^{17}$ Case 81/87 [1988] E.C.R. 5483. 
operations within their respective jurisdictions and that freedom of establishment under EC Treaty, arts 43 and 48 was not conditional on the adoption of a convention since the Articles in question had been directly applicable since the end of the transitional period. ${ }^{18}$

On the ECJ's view of Daily Mail, its finding in Überseering is not to be taken as abrogating the ability of a Member State to restrict the right of a company incorporated in its jurisdiction from retaining legal personality under its law in the event of the company wishing to transfer its centre of administration to another Member State. This might be seen as drawing a somewhat fine and impractical line between the powers of the original Member State of incorporation and the powers of the destination State to which a company has transferred. In seeking to explain what has been described as an arbitrary distinction, ${ }^{19}$ the Advocate General, RuizJarabo Colomber, noted in his Opinion in Überseering that it has been said to follow from the fact that it falls within the exclusive competence of the home state to determine the rules applicable to a company's legal existence in accordance with the applicable rules of private international law.

Second, the Spanish government's contention that Überseering did not satisfy Title I of the General Programme which requires, as a condition for freedom of establishment, companies to have a real and continuous link to the economy of a Member State, was also dismissed. The Court stressed that this requirement applies where a company has only its registered office within the Community whereas Überseering had both its registered office and centre of administration within the Community. Finally, on the question raised by the German government of whether placing a restriction on freedom of establishment was justified by the overriding requirement of protecting the general interest, ${ }^{20}$ such as the interests of creditors, minority shareholders, employees and the tax authorities, the ECJ thought that in certain circumstances and subject to certain conditions this might be conceivable. However, on the facts before it, such objectives could not be harnessed to deny legal capacity to a company that is a party to legal proceedings where its registered office is in another Member State. The German position was therefore disproportionate. It is noteworthy that although the Court did not specifically rule against the real seat principle, it is difficult to see how in practice it can

${ }_{18}^{18}$ Para. 59 of the judgment.

${ }_{19}$ See Wooldridge, note 14 above.

${ }^{20}$ Apart from the overriding reasons relating to the public interest, EC Treaty, art 46 also permits Member States to restrict the freedom of establishment of foreign nationals in so far as such restrictions can be justified on grounds of public policy, public security or public health. 
survive as a legitimate conflicts rule given that Germany's refusal to recognise the company's legal capacity to sue was held to be an infringement of its freedom of establishment.

\section{INSPIRE ART}

Inspire Art Ltd. was incorporated in July 2000 as a private limited company in England. Its registered office was at Folkestone and its sole director was domiciled in the Hague. The company traded exclusively in the Netherlands. Articles 1-5 of the Netherlands statute (WFBV (Law on Formally Foreign Companies)) impose stricter conditions on private companies, including foreign companies, than are required under the UK Companies Act 1985. Article 1 of the WFBV defines a foreign company as a capital company formed under laws other than those of the Netherlands and having legal personality, which carries on its operations entirely or almost entirely in the Netherlands and which does not have any real connection with the State within which the law under which the company was formed applies. Article 2 of the WFBV requires foreign companies to register as such in the commercial register of the host State. Article 4(1) and (2) provide that the subscribed capital of a formally foreign company must be at least equal to the minimum amount required of Netherlands limited companies by the Netherlands Civil Code (EUR 18,000 in September 2000) and the paid-up capital to be at least equal to the minimum capital. Should the conditions contained in Article 4(1) and (2) not be met, the directors are jointly and severally liable with the company for all legal acts carried out during their directorship which are binding on the company. Further, directors of a formally foreign company are similarly jointly and severally liable for the company's acts if the capital subscribed and paid up falls below the minimum required. Article 5 concerns the keeping of accounts by directors of foreign companies and the requirement of an annual report in line with the annual documents required of Netherlands companies.

The company registered in the commercial register of the Chamber of Commerce without stating that it was a foreign company within the meaning laid down by Article 1 of the WFBV. The Chamber of Commerce therefore petitioned the Kantongerecht Amersterdam on 30 October 2000 for an order that the register be rectified so as to state that Inspire Art Ltd. is a foreign company. The effect of such rectification would be to trigger the other conditions laid down in the WFBV. In its defence, the company denied that its registration was incomplete on the basis that it did not fall within the definition contained in Article 1 of the WFBV. It 
further contended that if the Kantongerecht ruled that Article 1 applied, the conditions laid down in the WFBV were contrary to Community law in so far as they impeded freedom of establishment. The Kantongerecht held that Inspire Art Ltd. was a pseudo-foreign company within the meaning of Article 1 and it stayed the proceedings in order to refer to the ECJ the following two questions. First, whether EC Treaty arts 43 and 48 are to be construed as precluding the Netherlands from attaching additional conditions such as those contained in Articles 2-5 of the WFBV to the establishment in the Netherlands of a branch of a company incorporated in the UK with the sole purpose of securing advantages which that offers as compared to incorporation under Netherlands law? In this regard, Netherlands law presumes that purpose from the fact that the company carries on its operations entirely or almost entirely in the Netherlands and does not have any real connection with the State in which it is incorporated. Second, if the provisions of the WFBV are construed as being incompatible with Community law, must EC Treaty art $46^{21}$ be interpreted as meaning that EC Treaty arts 43 and 48 do not affect the applicability of the Netherlands rules laid down in the WFVB, on the ground that the provisions in question are justified for the reasons stated by the Netherlands legislature?

The Chamber of Commerce together with the governments of the Netherlands, Germany, Italy and Austria submitted that the provisions of the WFBV are not contrary to the freedom of establishment conferred by EC Treaty arts 43 and 48. It was argued that the requirements laid down in the WFVB did not relate either to the formation of companies under the law of another Member State nor to their registration and consequent recognition, but rather the validity of such companies is in fact recognised by the WFBV in that they are not refused registration. The central plank of their submission in this regard was, therefore, that Centros was irrelevant to the present case because that decision is concerned solely with the rule governing registration of foreign companies without affecting a Member State's freedom to require that certain conditions be met prior to trading. ${ }^{22}$ It was further submitted that the Daily Mail case decided that EC Treaty arts 43 and 48 did not disentitle Member States from determining the relevant connecting factor to their national legal order and that, in effect, it was held that freedom of establishment did not preclude the adoption under private international law of rules applying to companies falling within the ambit of Netherlands law. On this basis, the

${ }^{21}$ See note 20, above.

22 Paras. 74-76. 
Governments submitted that the WFBV does no more than attach significance to the place in which the company operates in addition to the connecting factor of the place of incorporation. In their opinion, the WFBV conditions are non-discriminatory because they are mandatory rules of Netherlands company law applicable to all limited liability companies formed in the Netherlands and that their purpose is to safeguard non-economic interests recognised at Community level relating to consumer and creditor protection.

The Netherlands government also went on to point to its liberal stance towards recognising companies validly incorporated in other Member States but that its "accommodating system" had led to "increased use of foreign companies for ends which the Netherlands legislature had not covered or even foreseen". ${ }^{23}$ The result, in its view, was that with increasing frequency companies carrying on their activities principally or even exclusively in the Netherlands are formed in other States with the aim of evading the overriding requirements of Netherlands company law. Thus, to address that development it argued that Article 6 of the rules-of-conflict Law establishes a limited exception to that liberal regime by providing that the WFVB provisions apply. The German and Austrian governments took the view that freedom of establishment, as it applies to branches, is aimed at enabling undertakings to carry on operations in one Member State while achieving growth in another Member State: "which is not so in the case of brass-plate companies". ${ }^{24}$ They questioned whether branches of formally foreign companies ought to be regarded as principal establishments so that there ought to be applied to them the principles of freedom of primary establishment. On this view, the Italian government went on to reason that the fact that a company established in one Member State has never carried on any operations in that State means that it should not be regarded as a branch when it operates in another Member State. In this scenario the location of the company's centre of administration determines which State is its primary establishment. If this line of argument were taken to its logical conclusion it would effectively mean that the seat doctrine, a conflict of laws concept, should be applied to determine the scope of free movement rights. Although this has the twin attractions of logic and simplicity, not surprisingly the ECJ refused to succumb to it.

Finally, it was argued by the governments of the Netherlands, Germany and Italy that ECJ caselaw recognises the right of Member States to implement measures designed to prevent

23 Para. 79.

24 Para. 84. 
improper or fraudulent evasion of national legislation under the cloak of Community law. ${ }^{25}$ While recognising that merely carrying on operations exclusively in a second State is not sufficient reason for denying freedom of establishment by pleading abuse, deceit and/or the unacceptable evasion of national law, nevertheless the governments submitted that the WFBV does no more than provide for some limited preventative measures and penalties where a company evades the overriding rules of company law applicable in the State in which all operations are carried on. ${ }^{26}$ Consequently, on the facts of the present case if Inspire Art Ltd. were able to plead successfully freedom of establishment, that would be tantamount to permitting unacceptable evasion of national law that is permitted by Community law as it stands.

Against this formidable range of submissions, Inspire Art Ltd., the UK and the Commission responded that the provisions of the WFBV impede freedom of establishment because their stated purpose is to impose on formally foreign companies conditions which render the right of establishment markedly less attractive for those companies. Indeed, on the basis of Centros, ${ }^{27}$ they argued that it is immaterial whether a company incorporated in one Member State but which operates exclusively in another is doing so in order to avoid the stricter legislative obligations imposed by the national law of the second Member State. Indeed, the caselaw holds that such conduct is merely the exercise of freedom of establishment. Further, it was submitted that the test of actual activity as the connecting factor adopted by Article 1 of the WFBV in order to determine whether the mandatory obligations in Articles 2-5 trigger does not correspond to any criterion provided for in EC Treaty art 48. As such, it infringes the right of establishment insofar as it makes the exercise of that freedom less attractive to companies formed in another Member State and which intend subsequently to carry on its operations in the Netherlands.

In line with the submissions put forward by Inspire Art Ltd., the UK government and the Commission, the ECJ held that it is contrary to Article 2 of the Eleventh Council Directive 89/666/EEC (concerning disclosure requirements of branches opened in a Member State by certain types of company governed by the law of another Member State $^{28}$ ) for national legislation such as the WFBV to impose on the branch of a company formed in accordance with

${ }^{25}$ See Centros Ltd. v. Erhversus-og Selkabssyrelsen, note 1 above, para. 24.

${ }^{26}$ Para. 88.

${ }^{27}$ Also citing Case 79/85 Segers [1986] E.C.R. 2375.

${ }^{28}$ See note 13, above. The object of the Directive in this respect is anti-avoidance, i.e. to ensure that companies cannot avoid the disclosure requirements of another Member State by operating through a branch as opposed to a subsidiary company. 
the laws of another Member State disclosure obligations not provided for by that directive. Further, it held that is contrary to EC Treaty arts 43 and 48 for national legislation to impose on the exercise of freedom of secondary establishment in that State by a company incorporated in another Member State certain conditions relating to minimum capital and directors' liability. The Court laid considerable emphasis on the point that the reasons for which a company is formed in another State, and the fact that it carries on its operations exclusively or almost exclusively in the Member State of establishment, do not deprive it of the right to invoke the freedom of establishment guaranteed by the EC Treaty unless the existence of abuse is established on a case-by-case basis.

\section{CONCLUSION}

Inspire Art is significant because unlike the Daily Mail, Centros and Überseering cases that were principally concerned with registration and procedural questions, the ECJ confronted substantive company law issues. The legality of national laws which impede the exercise of EC Treaty freedoms will be tested by reference to four conditions: they must be non-discriminatory; they must be necessary in order to protect a public interest objective; they must be suitable for securing the attainment of the objective they are designed to address; and they must be proportionate. ${ }^{29}$ The approach of the Court implicitly recognises the reality that the EC's company law harmonisation programme is putting in place certain core standards across the jurisdictional divides within the Community. The decision would seem to confirm that the Eleventh Company Law Directive is exhaustive so that Member States are not entitled to add further disclosure requirements. The effect of Inspire Art therefore is to place a severe restriction on the freedom of Member States to construct their own legislative regimes designed as protective measures. Further, following Centros and Überseering it might have been convincingly argued that provided Member States recognised the legal personality of companies operating within their jurisdictions though incorporated elsewhere then they were free to disregard the fundamental attribute of the limited liability of members of such companies. However, such a view now seems untenable given that mutual recognition must now extend both to the entity and to its attributes.

Beyond the narrow parameters of national corporate law regimes critical questions remain unresolved. For example, will the

${ }^{29}$ See paras. 107 and 133. Applying Case C-19/92 Kraus [1993] E.C.R. I-1663, para. 32; Case C55/94 Gebhard [1995] E.C.R. I-4165, para. 37; and Centros, above note 1, para. 34. 
Court view the creditor protection measures contained in the Insolvency Act $1986^{30}$ and the Company Directors Disqualification Act 1986 as obstacles to freedom of establishment. Will a director who is disqualified as unfit on the basis of his or her capricious disregard of creditors' interests, ${ }^{31}$ be able to incorporate a company in another Member State and return to the UK to operate the business? A solution based on ring-fencing national insolvency laws as distinct regimes not to be equated with a Member State's company law concerned with incorporation and establishment is hardly convincing. ${ }^{32}$ Nevertheless, Davies has acknowledged that such ring-fencing might be a possible way forward in relation to the mandatory rules on employee representation at board level where the state of incorporation has no such requirement. He concludes that such rules may well be viewed as part of labour law rather than of company law. ${ }^{33}$ For those who seek a more principled approach towards the delineation of company law some comfort may be taken from the proposal of the High Level Group of Company Law Experts to review the concept of an E.U. wide sanction of directors' disqualification. ${ }^{34}$

With respect to Überseering, it was commented above that the seat doctrine must now be viewed as unworkable in practice. By characterising the case as involving secondary establishment the Court was effectively denying the validity of the doctrine because under that theory this was, in reality, a case involving the relocation of a primary establishment (i.e. the real seat). This somewhat expedient approach has the merit of aligning the jurisprudence with the view of the High Level Group on Company Law which, in its Final Report, concluded that the obstacles which the seat doctrine raises against a company intending to transfer its centre of administration to another Member State must be reduced if cross-border restructuring of industry is to be realistically promoted. ${ }^{35}$ The Group notes that almost all of the respondents to

${ }^{30}$ See particularly the fraudulent and wrongful trading provisions contained in sections 213 and 214 respectively.

31 See Re Barings plc [1999] 1 B.C.L.C. 433; affd [2000] 1 B.C.L.C. 523 (CA).

32 Although, that said, the division between the two regimes was acknowledged by the government in its recent White Paper, Modernising Company Law (Cm. 5553-I and II), in which it proposes, for the purposes of company law reform at least, to keep the company and insolvency law regimes distinct: see paras. 3.12-3.13. Such a position could well be taken were the point to be litigated in the ECJ as a conflicts issue. Indeed, this has led to the Netherlands adopting the expedient but inconsistent line of applying its insolvency law on the basis of the real seat doctrine.

33 P.L. Davies, Gower and Davies Principles of Modern Company Law (London 2003) at p. 125.

${ }^{34}$ See Chapter III of the Final Report of the High Level Group of Company Law Experts on a Modern Regulatory Framework of Company Law in Europe, Brussels, 4 November 2002. This proposal was welcomed by the Law Society in its comments submitted to the European Commission Company Law Committee (February 2003, No. 454).

35 Ibid, ch. VI, Corporate Restructuring and Mobility. 
its consultation exercise called for a Fourteenth Company Law Directive on Transfer of Registered Office and that:

There was almost unanimous agreement that for a Member State to adopt a version of the real seat doctrine which automatically denies recognition to a company which has its "real seat" in a country other than that of its incorporation was a disproportionate measure which can never be justified. We agree with this view, and believe that it is likely to be against E.U. law to take such an approach. ${ }^{36}$

The rejection of the submission in Inspire Art that the protective measures contained in the WFBV were justified in the interests of shareholders and creditors aligns substantive E.U. law with the policy objectives outlined by the High Level Group of Experts. As indicated above, the Final Report proposes that the emphasis of company law should be shifted away from the protection of creditors and members and should be focused upon providing a regime "for those who wish to undertake business activities efficiently, in a way they consider to be best suited to attain success. Company law should first of all facilitate the running of efficient and competitive business enterprises". ${ }^{37}$ This is not to say that such protective measures were not a legitimate concern of company law, but the Group concluded that "an important focus of the E.U. policy in the field of company law should be to develop and implement company law mechanisms that enhance the efficiency and competitiveness of business across Europe". ${ }^{38}$ Nevertheless, myriad issues remain to be addressed by the proposed Fourteenth Company Law Directive if an appropriate balance is to be struck between facilitating cross border enterprise while at the same time protecting creditors and shareholders against abuse. While disclosure is viewed by the High Level Group as the central regulatory tool this requires some measure of reinforcement by clearly drafted and workable substantive rules. As it stands there are fundamental defects with the drafting of the proposed Directive. For example, Art 8 is directed towards protecting creditors by permitting them to demand of the company "adequate security" prior to its transfer to another Member State. The obvious problem that arises in this respect is that having obtained an undertaking relating to priority of payment (i.e. adequate security), this may become worthless in the event of the company creating another body of secured creditors in the new Member State whose priority

\footnotetext{
${ }^{36}$ Above note 32, para. 2.1. The proposed Fourteenth Directive, which was first mooted in 1992 following the decision of the ECJ. in the Daily Mail case, above note 17, was published in 1997.

${ }_{38}^{37}$ Above, note 34, ch. II, General Themes, para. 1. See also note 16 above, and associated text.

${ }^{38}$ Ibid.
} 
will then be determined according to the insolvency law of that jurisdiction. This might have the unfortunate consequence of leaving the creditors in the original state of incorporation high and dry. With respect to shareholders, Art 6 confers the right to decide upon a transfer of seat to another Member State to the general meeting by a two-thirds vote or, if at least 50 per cent of the company's capital is represented, by an ordinary resolution. This fails to take account of differing class rights or the views of other interested constituencies such as employees or creditors. More generally, there are serious drafting deficiencies with other key provisions contained in the proposed Directive. Thus, Art 11(2) states that a Member State may refuse to register a company if its central administration is not located in that Member State. On its face, this seems to run a coach and horses through the overriding objective of freedom of establishment.

These issues aside, although it is still early days to reach any firm conclusions on the likely reach of these recent cases, it seems that they represent the first steps towards attaining joined-up thinking between the ECJ and the Community policy makers. The decisions also represent an important step in the evolution of the ECJ's jurisprudence in so far as the Court is now beginning to apply internal market principles within the realms of company law and private international law. While the ECJ might in the past have been accused of taking an overly cautious approach towards conflict issues, it has now come down firmly in favour of giving priority to internal market principles by rejecting arguments based upon the perceived need of Member States to ring-fence company and conflicts laws. 